\title{
Chalkley Score
}

National Cancer Institute

\section{Source}

National Cancer Institute. Chalkley Score. NCI Thesaurus. Code C158254.

A microscopic measurement of the volumetric or area ratios of components of tissues or organs. (Chalkley HW. Method for the quantitative morphological analysis of tissues. J Natl Cancer Inst; 4: 47-52) 